\title{
RECOVERIES OF THE COMMON CROW BANDED IN SASKATCHEWAN
}

by C. Stuart Houston, 863 University Drive, Saskatoon

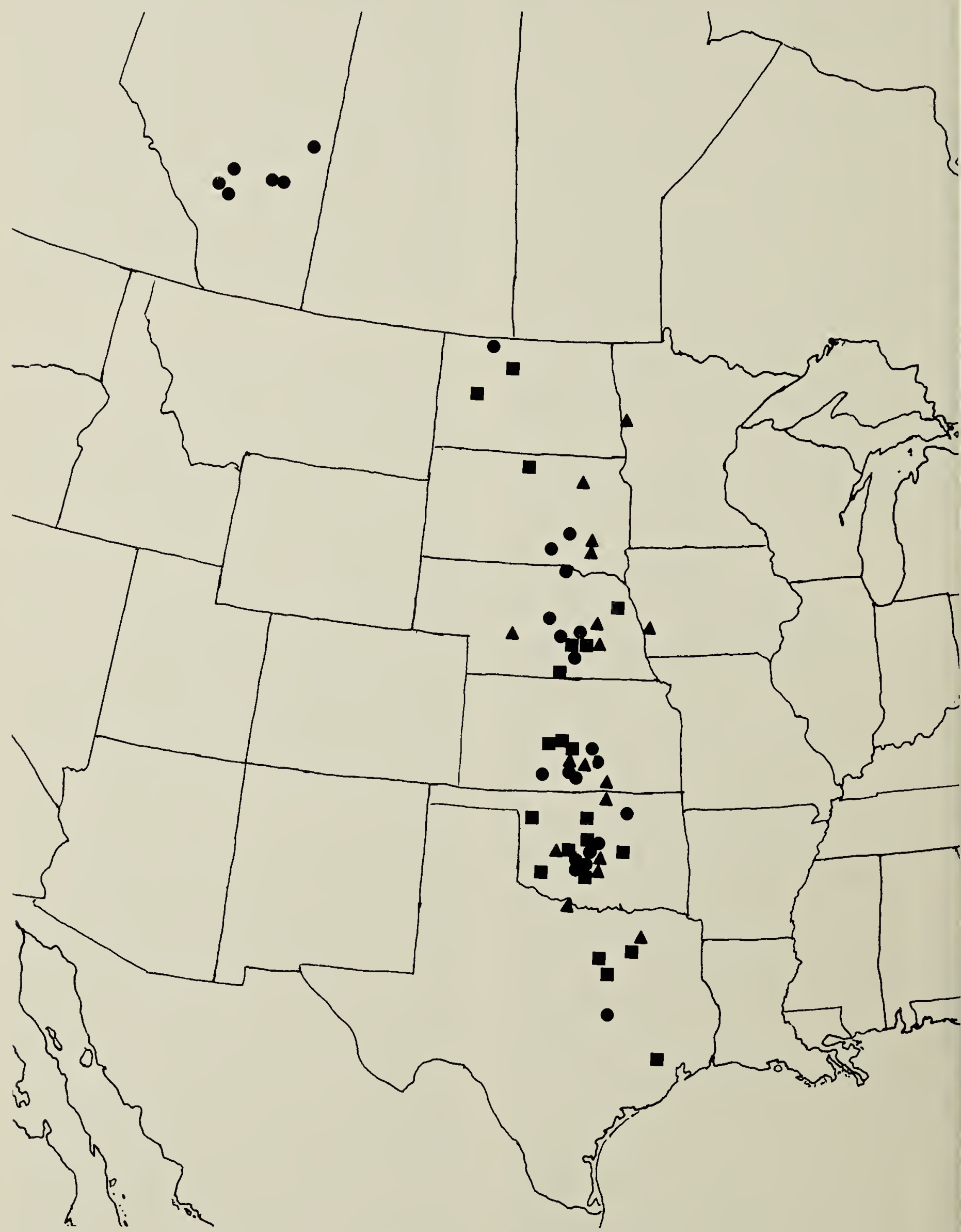

Recoveries of Common Crows banded in Saskatchewan (Saskatchewan recoveries excluded). Note: Squares represent direct recoveries (same year). Triangles-January 1 to June 30 of the following year. Circles-more than one year old. 
Saskatchewan crows appear to follow a remarkably narrow migration flyway, more restricted than for any other Saskatchewan species. The 59 U.S.A. recoveries are confined to the narrow tier of states from North Dakota to Texas (see map), with two minor exceptions, of crows that crossed over to the east bank of the Red and Missouri Pivers, respectively, to be shot just within the borders of Minnesota and Iowa. The great majority were shot and since crows are hunted the year round, an unusually large number were recovered in the second six months of their life -after January 1st of the following year. Such birds are listed as "-1 yr." of age, and are depicted as triangles on the map; hence there are more triangles on the crow map than for other species. Saskatchewan recoveries are not mapped, but two crows reached an age of eight years.

Special mention must be made of the extensive banding by Fred G. Bard in 1936, 1937 and 1938. Unlike the immatures (almost all nestlings) banded by other banders, these were adult crows trapped and banded as part of a crow control campaign. At that time, crow predation on duck nests was believed to play a large role in the decline of waterfowl numbers. To encourage hunters to shoot crows, there were prizes for shooting banded crows and certain band numbers carried more valuable awards. In 1938, for example, 250 crows were banded. They were released at widely different Saskatchewan points, usually two at each ten mile interval. Hunters soon learned to shoot selectively those crows with bands and continued this even after Mr. Bard resorted to painting the bands black to make them less obvious in the sunlight!

Thus Bard's adult crows had an unusually high number recovered in Saskatchewan the same year as banded (96), compared to Saskatchewan in later years (31), and a relatively small number were recovered in the United States $(18$, with none

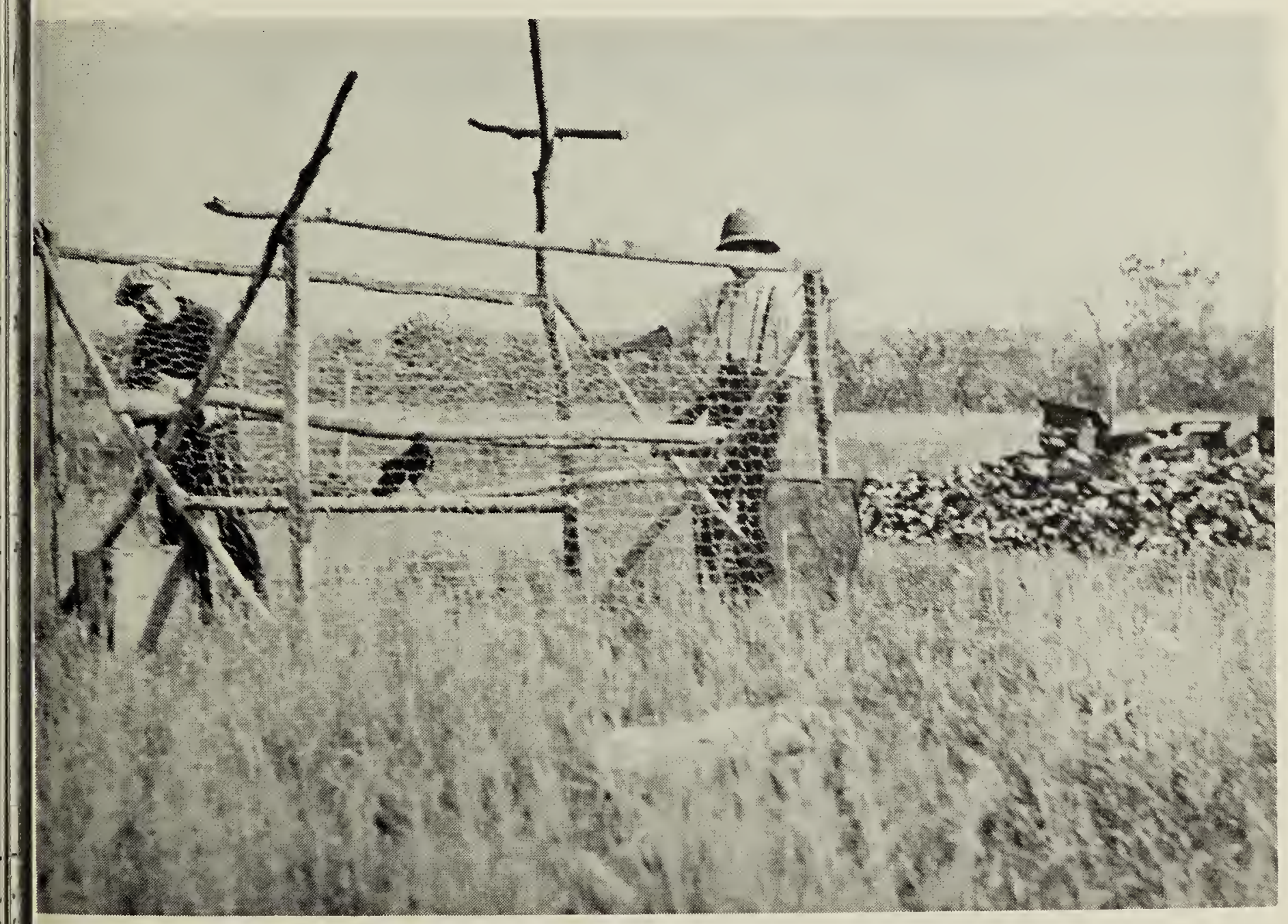

Trapping adult crows for F. G. Bard's banding projects. 
direct, before January 1st). Six were recovered from Alberta in later years. No nestling crows raised in Saskatchewan have yet been recovered in Alberta, and one can only assume that some crows of Alberta origin share the same flyway, with the birds raised in Saskatchewan.

The following records of sixteen banders are from computer printouts obtained from the Canadian Wildlife Service, through Dr. J. B. Gollop. After the date of banding, the next column lists "A" for adult, " $I$ " for immature, "U" for unknown and " $\mathrm{L}$ " for nestlings or local flightless young. In fact, most of the "immatures" were banded in the nest but a differentiation was not made in the records of those days. "Direct" means a bird recovered during its first southward migration, before December 31 of its first year. $373-0992$ means $37^{\circ} 30^{\prime} \mathrm{N}$. and $99^{\circ} 20^{\prime} \mathrm{W}$.

On the map, squares represent the direct recoveries, to December 31 of first year, triangles represent the next six months, and circles represent birds more than one year of age.

Banded by R. H. Carter, Muscow, Sask. (504-1035): (155 banded)

June 24/:3. I. Shot April 18/24 (-1 yr.) Warner S.D. (451-0982).

June 30/26. I. Shot March 26/27 (-1 yr.) Parkston, S.D. (432-0975).

June 21/31. I. Shot April 13/36 ( -5 yr.) Kenmare, N.D. (484-1020).

June 26/32. I. Shot mid-Nov./32 (direct) Franklin, Nebraska (400-0985).

June 19/52. I. Shot Jan. 11/53 (-1 yr.) in Kansas (370-0980).

Local: Shot at 1 month, 2 yrs., 4 yrs., 6 yrs. and 7 yrs. and killed by dog at 5 yrs.

In Sask.: Poisoned at Craik at 1 yr., found dead at Neville -2 yrs., injured Odessa -1 yr.

Shot at Windthorst 1 yr., North of Grenfell -4 yrs., Indian Head 5 yrs.

Banded by J. R. Carter, Muscow, Sask. (504-1035): (11 banded)

June 30/34. L. Shot Jan. 4/38 (-4 yr.) in Oklahoma (345-0975).

June 30/34. L. Shot Nov. 6/34 (direct) in Kansas (381-0990).

In Sask.: Shot at Meota -2 yrs.

Banded by J. A. Briggs. a)Biggar (503-1051); b) Buffalo Pound L. (503-1051): June 15/27. I. Shot Oct. 11/27 (direct) in Nebraska (425-0985).

June 28/27. I. Shot Nov. 13/27 (direct) in Kansas (380-0982).

July 15/39. I. Shot Feb. 26/41 (-2 yr.) in Kansas (380-0974).

Local: Hit by train same month, shot same month, shot same year.

Other Sask.: Biggar to Xena (514-1053) at 8 yrs.; Regina to Valley Centre (514-1075) at $1 \mathrm{yr}$.

Banded by J. A. M. Patrick, Yorkton, Sask. (511-1052) :

June 19/31. U. Shot Jan. 16/32 (-1 yr.) in Oklahoma (352-0984).

Banded by George H. Lang, Indian Head, Sask.s. (503-1034) : (83 banded)

June 23/24. I. Shot Jan. 21/25 (-1 yr.) Lexington, Okla. (350-0972).

June 19/32. I. Shot mid-Feb./35 (-3 yr.) in Oklahoma (368-0968).

Local: Shot next month and 8 yrs.; Killed result of weather -2 yrs.

Banded by Wotherspoon Bros., Hyas, Sask. (515-1021): (23 banded)

June 24/34. I. Shot Jan. 21/:6 (-2 yrs.) Sargent, Nebraska (413-0992).

June 24/34. I. Shot Dec. 22/34 (direct), Wisner, Nebraska (415-0965).

June 25/37. I. Found dead Feb. 15/39, (-2 yrs.), Blanchard, Okla. (350-0973).

Also 3 shot locally same month; 1 shot at Fulda, Sask. at -6 yrs. 
Banded by W. F. Hammond, Cupar, Sask. (505-1041): (150 banded).

June 3/33. A. Shot Oct. 14/33 (direct), Rush Springs, Okla. (344-0975).

June 27/33. A. Shot Nov. 28/38 (5 yrs.) Mullinsville, Kansas (373-0992).

June 30/33. A. Shot March 18/34 (-1 yr.) Ashton, Kansas (370-0971).

July 3/34. A. Shot early Nov./34 (direct), in Texas (323-0972).

July 3/40. I. Shot Dec. $3 / 40$ (direct), Prague, Okla. (352-0964).

July 3/40. I. Shot March 24/41 (-1 yr.) York, Nebraska (405-0973).

Local: Shot -3 yrs., shot at nearby Markinch at 4 and 5 yrs. and injured at Markinch at $1 \mathrm{yr}$. and found dead at Dysart at -2 yrs.

Other Sask.: Poisoned at Grenfell at 1 yr.

Banded by J. A. Gold, Golden Prairie, Sask. (492-1041):

June 23/35. I. Band obtained May 4/36 (-1 yr.) Radville, Sask. (492-1041).

Banded by Farley M. Mowat, Saskatoon (520-1064):

Local: 1 shot 2 yrs. later.

Banded by R. O. Hedlin, Renown, Sask. (513-1053):

June 23/38. I. Shot Nov. 5/38 (direct) in Texas (321-0971).

June 24/38. I. Shot Feb. 10/40 (-2 yr.) in Oklahoma (353-0983).

July 1/38. I. Caught in trap Nov. 27/39 (1 yr.) in Nebraska (411-0981).

Sask.: 1 shot at Tichfield at $1 \mathrm{yr}$., and shot at Lanigan at $1 \mathrm{yr}$.

Banded by C. S. Houston, Saltcoats, Sask. (510-1020 and 1021): (127 banded)

June 22/57. L. Shot March 5/60 (-3 yr.) Hastings, Neb. (403-0982).

June 6/58. L. Shot Nov. 2/58 (direct) Blair, Okla. (344-0991).

June 9/58. L. Shot Oct. 25/58 (direct) Grand Island, Neb. (405-0982).

Local: Shot at $1 \mathrm{yr}$. and found dead at $2 \mathrm{yr}$.

Banded by F. J. H. Fredeen, Macrorie, Sask. (511-1070):

June 16/40. I. Found dead Nov. 15/40 (direct) Nebraska (405-0982).

June 22/41. I. Shot Oct. 21/41 (direct) in South Dakota (453-1002).

July 18/42. I. Shot Dec. 23/42 (direct) in Oklahoma (351-0993).

Banded by \#5498, Woodrow, Sask. (493-1064):

June 20/47. I. Shot Oct. 31/48 (1 yr.) in Oklahoma (348-0988).

Local: Four shot same year, one after 1 yr., two after 2 yrs.

Banded by Bill Anaka, Spirit Lake, Sask. (513-1024):

June 19/60. L. Shot Oct. 9/60 (direct) in Kansas (381-0984).

Local: 1 shot same year; at nearby Canora, one shot same year and three at 3 yrs.

Banded by Dr. J. B. Millar a) Saskatoon (520-1063); b) Melfort (525-1043); c) E. of Swift Current (501-1073); d) NE of Old Wives Lake (501-1054):

a) June 30/62. L. Dead before May 4/64 ( -2 yr.) in S.D. (434-0985).

b) June 4/64. L. Shot Oct. $3 / 64$ (direct) in N. Dakota (472-1024).

c) June 8/64. L. Shot Nov. 28/64 (direct) in Texas (295-0957).

a) June 18/64. L. Shot Sept. 17/64 (direct) in N.D. (481-1012).

a) June 18/64. L. Shot Dec. 15/64 (direct) in Oklahoma (351-0982).

a) June 18/64. L. Shot Dec. 12/65 (1 yr.) in Kansas (375-0974).

d) June 24/65. L. Shot Oct. 10/65 (direct) in Texas (324-0962).

Local: Eight shot the same year, two after two years.

Other Sask. (all within 30 miles): two the same year, three at $1 \mathrm{yr}$.

Banded by Fred G. Bard, southern Sask., released 493 to $533 \mathrm{~N}$ and 1014 to $1090 \mathrm{~W}$ :

June 20/35. A. Shot Oct. 14/35 (direct) in Oklahoma (341-0975).

June 9/36. A. Shot Jan./37 (-1 yr.) in Kansas (375-0983).

June 9/36. A. Shot Jan. 3/38 (-2 yr.) in Kansas (374-0982).

May 14/37. A. Shıt March 22/38 (-1 yr.) in Iowa (411-0955). 
May 14/37. A. Shot Feb. 9/40 (-3 yr.) in Texas (310-0970).

May 14/37. A. Shot Feb. 5/38 (-1 yr.) in Nebraska (410-1004).

May 20/37. A. Shot Jan. 22/38 (-1 yr.) in Oklahoma (364-0971).

May 27/37. A. Shot Jan. 22/38 (-1 yr.) in Nebraska (412-0974).

May 27/37. A. Shot Jan. 2/39 (-2 yr.) in Oklahoma (345-0980).

May 27/37. A. Shot Jan. 19/38 (-1 yr.) in S. Dakota (432-0975).

June 9/37. A. Shot Feb. 24/38 (-1 yr.) in Texas (330-0960).

June 9/37. A. Miscellaneous cause, Dec. 1/38 (1 yr.) in Neb. (410-0985).

June 23/37. A. Found dead April 15/38 (-1 yr.) in N.D. (465-0964).

Aug. 31/37. A. Shot Dec. 2/38 (1 yr.) in Oklahoma (345-0981).

May 11/38. A. Shat July/41 (3 yr.) in Alberta (521-1122).

May 11/38. A. Shot July 8/39 (1 yr.) in Alberta (514-1143).

May 11/38. A. Shot July/41 (3 yr.) in Alberta (513-1140).

May 11/38. A. Shot June 10/44 (6 yr.) in Alberta (521-1140).

May 18/38. A. Shot Aug. 26/39 (1 yr.) in Alberta (521-1122).

May 18/38. A. Shat May 30/41 (3 yr.) in Alberta (532-1105).

May 19/38. A. Shot March 30/44 (-6 yr.) in Kansas (372-0981).

May 19/38. A. Shot March 24/39 (-1 yr.) in Kansas (373-0980).

May 21/38. A. Shot March 6/39 (-1 yr.) in Texas (335-0982).

June 14/38. A. Shot early April/40 (-2 yr.) in S.D. (438-0998).

July 9/38. A. Shot Jan. 23/39 (-1 yr.) in Oklahoma (345-0974).

In same or adjacent quadrant: Same year, 39 shot, 3 trapped, 1 killed by owl, 1 miscellaneous; at one year, 2 shot, 1 trapped; at two years, 2 shot.

Elsewhere in Saskatchewan: Same year, 45 shot, 7 trapped; at one year, 15 shot, 1 caught by hand; at two years, 5 shot; at three years, 2 shot; at four years, 1 shot; at five years, 1 shot; at nearly nine years, 1 shot.

\section{SOME 1968 SOUTHERN ALBERTA BIRD OBSERVATIONS}

\section{by Wayne W. Smith and Cleve R. Wershler, Calgary}

The purpose of this article is to put on record some interesting observations made in southern Alberta in 1968. Most of the observations were made in the Calgary area. On a few occasions, one or more of the following people were with us - Stu Alexander, Keith Seely, Red Mason, Ian Halladay, Jack Shier, and Garry McKay. In addition, Dave Thomae and Tom Sadler provided several of their personal observations. The observations show the variety and quality of southern Alberta for bird watching. Even a major city like Calgary has areas of great quality.

Pied-billed Grebe (Podilymbus podiceps). On June 13, one adult was found at the first Vermilion Lake, Banff National Park (Dave Thomae, pers. comm.). The next evening (June
14) a nest with seven eggs was found. On July 3 , one adult and 6 young (2-3 weeks old) were found on a slough about 10 miles north of Turner Valley (25 miles southwest of Calgary). These two records appear to be the first nestings recorded of this species in the mountains and foothills of Alberta.

Night Heron (sp.?) For three days (August 19-21) an immature heron was seen in Calgary (Inglewood). On one of these days we approached to within 25 feet of the bird, getting an excellent view, as it sat in a large willow. We observed the bird through 7-power binoculars and made field notes from which the following points were taken:

1. conspicuous yellowish bill (short and very thick for a heron). 